\title{
The political scenario in 1760
}

Party terminology in eighteenth-century Britain is a minefield of myth, prejudice, and contradiction. Not since the 1720s had the line between administration and opposition been one between Whig and Tory parties. Outside the main Whig government party, headed since 1754 by the Duke of Newcastle, there existed smaller Whig factions, varyingly in and out of office. In the 1750s only two were of real significance. One was a small talented family group in which the leading figures were the foremost Commons orator William Pitt and his two Grenville brothers-in-law, George and the wealthy Lord Temple. This group went into opposition in 1755. The other, in opposition since 1751, was the clique of peers headed by the Duke of Bedford.

Whigs in opposition naturally allied for tactical reasons with the dwindling rump of MPs, down to about 100 in the 1750s, whom many called Tory, because of their political ancestry and attitude of unvarying opposition. That pejorative designation was especially fixed on them by Whig ministers, to ensure that George I and George II excluded them from office, and there was some historical justification. Their championship of the privileged position of the Church of England, and resentment at Britain's involvement in Europe, both had roots in Tory attitudes before 1714. But the seventeenth-century Tory party had also supported the Stuart monarchy, and Whig propaganda therefore sought to affix to Tories the stigmata of support of absolutism and also of Jacobitism, that movement to restore the exiled Stuarts to the throne. Hence developed the myth that the Glorious Revolution of 1688 had been solely a Whig achievement, a claim unfair to Tories past and present. In 1770 'Sir William Bagot, a country gentleman of ancient family ... gave the most plausible and pleasing picture of a Tory that you can imagine', wrote Parliamentary 
diarist James Harris. 'He called them lovers of the Episcopal Church, but friends to toleration and the principles of the Revolution.'

There was therefore good reason for this standing opposition of Tory lineage to prefer the more respectable designation of 'the country interest'. The main thrust of their political stance was concern to curb the power of the Crown. For although the Revolution Settlement of William III's reign had prevented the emergence of an autocratic sovereign ruling in disregard of the law and without a Parliament, the subsequent growth of government power, civil and military, led to a different fear, that Parliament would be corrupted into compliance with the monarchy. Hence 'the country programme', designed to curb Crown influence over Parliament, comprising such ideas as Place Bills, to exclude office-holders from Parliament, some of which were enacted, and unsuccessful efforts to repeal the 1716 Septennial Act, on the ground that frequent elections would render MPs more responsible to their constituents.

This court-country dialogue was one chief political battleground of the earlier Hanoverian period. Foreign policy was the other. That was dominated by the concept of 'the Old System', the need for a European alliance against Britain's eternal foe France, antipathy towards this traditional enemy being reinforced in mid-century by increasing colonial and commercial rivalry. The concept was part of the Whig tradition, in contrast to the more isolationist one of a bluewater strategy, avoiding continental entanglements, associated with Tory ideas. This clash was in part merely a difference over tactics, as is apparent from this Whig view of Newcastle in 1749. 'France will outdo us at sea when they have nothing to lose by land ... Our alliances upon the continent, ... by diverting the expense of France, enable us to maintain our superiority at sea.'2 Apart from this Whig perception that it was in Britain's long-term interest to prevent French hegemony of western Europe, there had been since 1714 a second reason for the Old System, the concern of George I and George II, both born and bred in Hanover, for the safety of their beloved Electorate, which in effect deprived Britain of the advantage of being an island state. Since 1689 the Old System had been a triple alliance of Britain with two other states both fearful of French power, Austria, and Holland.

The seemingly eternal verities of home politics and foreign policy were suddenly ended by the coincidence of a political crisis consequent on the death of Prime Minister Henry Pelham in 1754 with a 
catastrophic start to another French war: hostilities began that year in North America, though not in Europe until 1756. The Duke of Newcastle could and did replace his brother at the Treasury, but he had to find a House of Commons Leader. ${ }^{3}$ William Pitt, the obvious candidate, would be an awkward colleague, for he was an advocate of maritime rather than continental warfare, and George II disliked him for his anti-Hanoverian stance. So Newcastle preferred Henry Fox, currently Secretary at War, a man reckoned by many to be a better debater than Pitt and one who would not quarrel with the Duke on policy. He was acceptable to the King as a friend of his son the Duke of Cumberland. But this arrangement lasted only until 1756, a year of disasters, notably the loss of Minorca, Britain's naval base in the western Mediterranean, and the failure of Newcastle's diplomacy. Britain thereby lost the traditional alliance with Austria, and therefore Russia also, Holland being now neutral, in exchange for the supposedly weaker help of Prussia. Newcastle resigned, but after an abortive attempt by Pitt to run the war without the Duke's Parliamentary majority, the two men formed a coalition ministry in June 1757 that reunited the whole Whig party in office for the first time in George II's reign: this arrangement Lord Temple famously later described as Pitt being 'minister of measures' and Newcastle as 'minister of numbers'. ${ }^{4}$ Pitt became Southern Secretary, with Temple in the cabinet as Lord Privy Seal; but Pitt failed to secure for Grenville the post he coveted of Chancellor of the Exchequer, in place of the incumbent, Henry Legge. Newcastle took the Treasury, but since his long-term confidant Lord Hardwicke refused to be Lord Chancellor again, Sir Robert Henley, created Lord Henley in 1760, became Lord Keeper of the Great Seal, a less prestigious version of the same post. Lord Holderness, a tame Secretary of State since 1751, remained as Northern Secretary. Also a fixture in the cabinet since 1751, as Lord President of the Council, was Lord Granville: formerly the Lord Carteret who had opposed and briefly succeeded Sir Robert Walpole, this nowmellowed statesman was to retain that post until his death in 1763 . Henry Fox was content to be without high office, making a notorious fortune as Paymaster of the Forces. The Duke of Bedford was recalled from opposition, being tactfully and tactically given the post of LordLieutenant of Ireland. More remarkable even than the unification of all Whig groups in government was the attitude of the Tories or 'country party'. In 1762 Pitt recalled that during the war he had enjoyed the support of 'many gentlemen who had been of the denomination of Tories': ${ }^{5}$ and on 21 April 1760, playing to the Tory gallery, 
this undoubted Whig even told the House of Commons that he was 'neither Whig nor Tory'. ${ }^{6}$ The Tories rallied to support Pitt as a minister whose professed strategy of maritime warfare accorded with their own idea of how to fight France. Both he and they were in that respect soon to learn wisdom from experience.

The political significance of George III's accession in 1760 has been reassessed in the light of these perceptions of the 1750s. No longer can any credence be given to the old tradition of a new King destroying a Whig oligarchy to put a Tory party in power. The era of political instability had already begun with the death of Henry Pelham in 1754 , and was not caused by the positive role of the young sovereign. That circumstance was disguised, and its consequence postponed, by the temporary wartime coalition of all the Whig factions in the Newcastle-Pitt ministry. There was no monolithic Whig party in power for the King to displace. Nor was there any semblance of a Tory party by which he could replace it. The political battles of the new reign were fought by men and factions who all called themselves Whig. In this party context George III's initiative was merely to remove his grandfather's proscription from honours and offices of those deemed Tory. They were now made welcome at the royal court, and five 'old Tories', headed by Lord Oxford, were soon appointed to the King's Bedchamber. All this aroused alarm and indignation among the 'old Whigs', especially Newcastle himself, but the Tories at Westminster did not constitute a positive factor in the political game. The picture has been confused by Sir Lewis Namier himself, the historian who destroyed the notion of a two-party system for this period. Namier constructed a much-cited but misleading list of 113 Tory MPs returned at the general election of $1761 .^{7}$ But this was put together from Parliamentary lists compiled by or for Newcastle between 1754 and 1766, and for the Duke 'Tory' was a generic term for politicians who always opposed him. Scrutiny of the list shows that at least twenty were Whig by any test, followers of Bedford or Leicester House or simply new MPs who sided against the Duke from 1761. One such was Sir Herbert Lloyd, whose family had been Whig since Anne's reign, and whose own father and brother had been Newcastle men under George II. Lloyd, who entered the Commons in 1761, obtained a baronetcy from Bute and voted against the Rockingham ministry's repeal of the Stamp Act, enough for Newcastle to label him a Tory. ${ }^{8}$

The 'old Tory' MPs numbered under a hundred in the 1760s, and they followed varying political paths. ${ }^{9}$ Each 'Whig' faction gained the 
support of some, and others became courtiers, but most merged into the loose body of independents. In Newcastle's 1767 Commons list, indeed, all independents were designated Tory. ${ }^{10}$ Others, like diarist James Harris, did distinguish 'old Tories', men like Sir Roger Newdigate, by the test of their championship of the Church of England. ${ }^{11} \mathrm{~A}$ broad focus of Tory unity was still provided by the Cocoa Tree coffeehouse in Pall Mall, which had been the London meeting-place of Tory squires in George II's reign. The phrase 'Cocoa Tree' continued to be a common political term to denote the supposedly collective behaviour of independent squires, usually of Tory stock. It was in this sense that Whig Sir James Lowther wrote in January 1770 to courtier Charles Jenkinson, 'I think we shall see the Tories unite in a body as much as ever, though perhaps under a different appellation, for ... the few who took places have now lost all interest at the Cocoa Tree. ${ }^{{ }^{12}}$ That forecast was erroneous, for the then incoming ministry of Lord North was perceived by many 'old Tories' like Newdigate to be so different from the Whig-led administrations of the 1760s as to merit their support. By George III's reign the Cocoa Tree was a club for likeminded men, not a political power base for a non-existent Tory Party.

The European alignment in what became known, but obviously not in America, as the Seven Years War saw Britain and Prussia overmatched by France, Austria and Russia. Against the odds the Anglo-Prussian partnership held out in North Germany. While Frederick the Great beat off the Austrians and the Russians, being rarely confronted by the two together, Prussia's western flank was protected against French attack by an army financed rather than contributed by Britain, and based in Hanover. Led by a German commander, Ferdinand of Brunswick, it achieved a notable victory at Minden on 1 August 1759, but the failure of the British cavalry under Lord George Sackville to press home an attack that might have converted a success into a rout led to a court-martial conviction that ended his military career: the disgrace did not put paid to his political prospects, and he was to become American Secretary in 1775 as Lord George Germain. From 1758 Britain also paid Prussia an annual subsidy of four million crowns, equivalent to $£ 670,000$, but no formal treaty of alliance was ever made. Early in 1760 the survival of Prussia still remained uncertain.

Overseas, by contrast, the war was proving a glorious triumph for Britain with success against France in America, Africa, and Asia. In 1760 the final conquest of Canada was imminent, and Britain's mastery of the sea had been confirmed by Admiral Sir Edward Hawke's 
defeat of the French navy at Quiberon Bay late in 1759: this ensured that France would not save the rest of her West Indies or recover her losses there, in West Africa, and in India. Pitt's achievement had been magnificent, and won him contemporary adulation. His reputation as the triumphant war minister secured him enduring popularity that he was to exploit as a politician. Nowadays he is no longer seen as the great war minister of legend, with a master plan for victory. His boast to Parliament on 13 November 1759 that America had been conquered in Germany was a retrospective rationalisation of a series of ad hoc decisions. ${ }^{13}$ Superior resources had been at his disposal, notably Britain's control of the high seas from the onset of hostilities. France had been defeated overseas because of her heavy European commitments, whereas until 1760 the German war had been cheap for Britain. Luck had played its part, in French incompetence and Spanish neutrality, but those advantages were now to end. In 1758 there came to power in France the Duke of Choiseul, who for the next twelve years strove to reverse the recent tide of disasters that had befallen his country. Aware that the overseas war was lost, Choiseul thought first of a direct invasion of Britain, and then sought territorial gains in western Germany as bargaining counters at the peace negotiations. His long-term aim was a war of revenge on Britain. $\mathrm{He}$ would have the support of Charles III of Spain, who from his accession in 1759 adopted an anti-British stance, fearful that Britain would next have designs on Spain's American Empire, and also bearing a personal grudge about British naval bullying in 1742 when he had been King of Naples, a threat of bombardment to coerce him into neutrality in the previous French war.

In 1760 the military situation in Germany was of more immediate concern to the British government than this latent Spanish threat. Prussia was in evident danger of defeat by Russia and Austria, and had lost her Rhineland territories to France. In 1760 Newcastle and Pitt, equally aware that America could still be lost in Europe, concurred in a change of strategy, pouring British soldiers into western Germany until in August the British commander there, Lord Granby, had to be told that no more men could be spared. Ferdinand of Brunswick, deploying 65,000 foreign troops in British pay as well as this British army, held off the still formidable French army in western Germany, but without a battlefield victory. Pitt knew it was a creditable performance, but one seemingly not good value for the $£ 14$ million the war cost Britain in 1760, and he rightly feared a political backlash at home. Even the long awaited news in September of the final conquest 
of Canada did not seem adequate compensation for the national effort in money and manpower, and Pitt therefore hit upon the idea of a maritime exploit that would satisfy national pride, the seizure of Belleisle, a fortified island off the west coast of France. It could serve as a naval base, and then as an exchange for Minorca. But Pitt failed to persuade the cabinet into agreeing to this expedition before the death of George II. ${ }^{14}$

That event had long posed a threat to the ministry of Newcastle and Pitt, both of whom had incurred the hostility of the Court of the Prince of Wales at Leicester House..$^{15}$ Newcastle for the young Prince symbolised everything that was wrong with his grandfather's reign: indulgence in expensive wars; corruption in government; and what he deemed to be the bridling of royal power. Pitt by contrast had once been high in favour at Leicester House, cultivating the Prince's tutor and mentor, Lord Bute, when in opposition in the mid-1750s, and in so doing aligning in a royal family quarrel with the Princess Dowager of Wales against her brother-in-law the Duke of Cumberland. As the war progressed this friendship had been transformed into hostility. Pitt had more important matters on his mind than the petty demands of Leicester House concerning patronage and information; and Leicester House disapproved of the military campaign in Germany that had soon formed an integral part of his war policy. At the end of 1758 the Prince wrote about Pitt to Bute that 'he seems to forget that the day will come when he must expect to be treated according to his desserts': and on 4 May 1760 he commented to Bute that he would not have 'the blackest of hearts' in his government. ${ }^{16}$

1760 was once deemed a watershed in British history because of the supposed political and constitutional intentions of the new King. Another emphasis on its significance now derives from the emergence of Britain as an imperial power. Empire replaced Europe as the chief focus of attention, for a period of peace after a generation of wars and international crises enabled attention to be given to imperial issues, old and new. There were long-standing problems in North America and Ireland, while new ones were posed by the acquisition of territories in India and North America.

But this historical perspective should not overshadow the contemporary obsession with the motivation and behaviour of George III that dominated the domestic political scene for much of the $1760 \mathrm{~s}$ and beyond. The old party terminology was revived, but to denote attitudes not men. Toryism was support for the new proactive role of the Crown, whereas Whiggism was the defence of liberty: this was the 
language of opposition, for it would be several decades before government politicians, as distinct from a few country squires, adopted the designation of Tory. The Duke of Newcastle in 1765 referred to 'this Tory reign', and the next year claimed that all his life he had served 'the Whig cause, which I will ever look upon, as the cause of liberty'. ${ }^{17}$ William Pitt as early as 1762 expressed 'his apprehension that the distinction of Whig and Tory was rising as high as ever ... that he would die a Whig'. ${ }^{18}$ In 1768 George Grenville, by then a former Prime Minister, defined Toryism as support of 'the power and authority of the Crown against the rights of the people'. ${ }^{19}$

Parliament was the chief safeguard of liberty against the Crown, and if it was to fulfil this role, party organisation there was a necessary ingredient. That was why the royal intention to rule in disregard of party so alarmed Parliamentary politicians. Grenville said in 1769 that 'Twas on the worst of principles of politics that the measure had been pursued of breaking all connections and partys'. ${ }^{20}$ The Rockingham group always held party to be the essence of politics, and the most famous contemporary defence of party came from Edmund Burke in his 1770 pamphlet Thoughts on the Present Discontents. 'Party is a body of men united, for promoting by their joint endeavours the national interest, upon some particular principle in which they are all agreed.' When in a Commons debate of 13 May 1768 Henry Conway attacked 'factious connections', he was answered by his former fellow Rockinghamites Lord John Cavendish and Edmund Burke, who both asserted that 'connections among persons of principle were right'. ${ }^{21}$ More remarkable was the endorsement of party, albeit qualified, by Camden, Lord Chancellor in the Chatham ministry that had been an avowed attack on such connections: in November 1768 Camden stated that 'twas right every man should follow his connections and act agreeably to them. That the man, who acted merely from his own sentiment, had no weight and could do little good - only a man should be careful not to go too far in following his friends - there were times and measures, when twas fitting to leave them'. ${ }^{22}$

Unconstitutional implications magnified the offence, in opposition eyes, of the King's conception of his political role. Lord Bute, whom at his accession he intended to make his Prime Minister, was a royal favourite, not even in Parliament until returned to the Lords in 1761 as a Scottish representative peer. Even after that reluctant Premier resigned in 1763, suspicion of his secret influence was a major political issue of the 1760s, and long survived in popular mythology even after Parliamentary politicians realised that it no longer had any validity. Grenville, 
his successor as Prime Minister, quarrelled with the King over the issue. George III stopped consulting Bute on political matters in March 1765..$^{23}$ Realisation of his loss of influence gradually dawned on contemporary perception. Parliamentary lists from 1767 ceased to include 'the Butes' as a separate party: and a note in Mrs Grenville's diary for 1768 demonstrated final awareness of the change. 'That the Earl's favour was over, and his credit gone, this is the language held universally. ${ }^{24}$

When by the late 1760s it was obvious that Bute's political influence was over, there developed the notion of 'a double cabinet', with the real power being in the hands not of the ministerial cabinet, itself an unofficial body in theory, but of a group of Bute's former followers, men like Sir Gilbert Elliot and Charles Jenkinson, at the head of a party of 'King's Friends'. Radical journalist John Almon wrote that 'there were about thirty persons who arrogantly assumed this appellation'. ${ }^{25}$ There was some foundation for the belief that certain politicians not in important offices were high in favour at the royal court. But the existence of a secret cabinet was pure fiction, and can hardly have been given credence by any politicians with knowledge of the inner workings of government. Yet it remained a point of popular propaganda into the American War, and John Almon expounded it as historical fact in his account of the period. 'It is necessary to observe, for the reader's information, that the system of the British Cabinet, since the accession of the present King, has been to maintain two Cabinets, one official, the other efficient. ${ }^{26}$

Opposition could hint at such suspicions of constitutional malpractice in Parliamentary debates, and they were widely voiced in the contemporary press; but such matters were too vague and too delicate to be raised directly by formal motions. Suspicion of corruption was another matter, and George III had an Achilles heel in the King's Civil List. Ironically the deficit was due not to the bribery of politicians, but to a naively high-minded decision of Bute and George III. Bute adopted a pledge of Frederick Prince of Wales in 1747 to a fixed Civil List of $£ 800,000$, and the Civil List Act of 1760 surrendered in lieu the royal revenues, then $£ 877,000$ and steadily rising. It was a disastrous bargain for the new young King, who apart from heavy initial expenditure, had far more family commitments than his grandfather - not merely his mother and uncle, but also a wife, children and adult siblings. George III's expenditure in the 1760 s averaged over $£ 900,000$ a year, wiping out a nest-egg left by George II, and in 1769 he asked Parliament to pay off a debt of $£ 513,000$. Since there was general realisation of the true state of affairs, opposition attempts to 
exploit the situation in Parliament failed dismally. ${ }^{27}$ The Civil List debt was a poorly chosen topic over which to attack the Crown, but for the moment there was no other: not until the 1770s was there again a country programme of proposals to limit government power. Political attention was diverted to the more urgent problems of empire, while the King's ministers found foreign policy more difficult than might have been expected after a successful war.

Foreign policy attracted more Parliamentary attention than the role of the Crown in the new reign, but no longer was it in the forefront of political attention. One reason was that George III's accession removed the Hanover factor. His antipathy towards his grandfather embraced detestation of what only a year earlier he described as 'that horrid Electorate which has always lived on the very vitals of this poor country'. ${ }^{28}$ George III's famous declaration to Parliament on 18 November 1760, 'Born and educated in this country, I glory in the name of Britain', was therefore of especial significance for the conduct of foreign policy. ${ }^{29}$ He never visited Hanover, and though British cabinets remained vaguely aware that the Electorate still represented a hostage to fortune, the King's lack of concern was so notorious that France made no attempt to seize it during the American War.

The absence of the Hanoverian complication paled into insignificance by comparison with the basic problem of finding an ally to combat the evident intention of Choiseul to seek revenge for France's defeat in the Seven Years War. In this respect George III was one of many British politicians who failed to perceive reality. In 1771 he still hankered after a return to the Old Alliance of the 1740s. 'England in conjunction with the House of Austria and the [Dutch] Republic seems the most secure barrier, ... and if Russia could be added to this, I think the Court of Versailles would not be in a hurry to commence hostilities. ${ }^{30}$ But Austrian Chancellor Kaunitz, in control of his country's foreign policy from 1753 to the French Revolution, found the French alliance he had contrived in 1756 highly advantageous: it secured peace in western Europe, so that Austria could safely pursue her ambitions in the east. No help on the European mainland, by contrast, could be expected from an insular and isolationist Britain, an opinion reinforced by the constant British ministerial changes of the 1760s, that led Kaunitz to believe that a Parliamentary government could not be a stable ally. But he wished to prevent Britain finding another ally, and so encouraged false hopes that the 'Old System' might yet be revived.

The King's misapprehension about the prospect of an Austrian alliance was shared by many British politicians, notably the Duke of 
Newcastle. Equally impracticable was the Pitt idea of reviving the wartime alliance with Prussia. Frederick II was well satisfied with the Russian partnership he achieved in 1764. That the other four Great Powers were paired off in alliances left Britain in isolation. The postwar situation, too, had changed in other ways to Britain's disadvantage from that before the Seven Years War. Her very success in that conflict meant that no longer could Britain seek to procure allies by the argument of a French threat to a European balance of power. It was anachronistic and obtuse of Northern Secretary Conway to write in 1767 that 'the liberties of Europe' were left 'at the mercy of the House of Bourbon'. ${ }^{31}$ For Choiseul had no ambition of continental hegemony, while Britain's deployment of her navy both to control neutral trade during the war and as a coercive diplomatic weapon afterwards served only to enhance the image of Britain, rather than France, as the bully of Europe. There had in any case been a shift in European perspectives. No longer did the other Great Powers regard the Anglo-French rivalry as the dominant factor in continental politics. The attention of Austria, Prussia and Russia was focused on Eastern Europe, the prospect of territorial plunder from the perceived weaknesses of Poland and the Ottoman Empire.

The failure of the traditional Whig policy of seeking anti-French allies in Europe led British politicians to adopt a Tory-style isolationist stance, behind the shield of the navy's 'wooden walls'. By 1767 the then First Lord of the Treasury Grafton could reflect that British policy was 'constantly to have a fleet in forwardness equal to what both houses of Bourbon could bring forth'. ${ }^{32}$ Financial economies introduced by that parsimonious Premier Grenville in fact denied the navy adequate funding. During the 1760s most of the fleet of 150 ships of the line were laid up, only a basic squadron of twenty guardships being kept in active service. This strategy sufficed to maintain British naval supremacy, since all Choiseul's efforts to rebuild the French navy foundered on lack of materials, manpower, and money, and so did the Spanish attempt. At the time of the Falkland Islands Crisis of 1770 some eighty British ships were soon fit for action, and there was every confidence Britain could defeat the combined enemy fleets. ${ }^{33}$

If the conduct of British foreign policy posed more problems than could be anticipated in 1760, the attention of both government and Parliament was increasingly taken up by imperial matters. One early issue was whether Britain should retain Quebec or the rich West Indies sugar island of Guadeloupe, also captured in 1759. A vigorous press debate was conducted in pamphlets rather than newspapers. 
Voices were raised that correctly anticipated the future course of events, putting the view that the older colonies would become more difficult to control if the French threat to them was removed. An additional argument for returning Quebec and keeping Guadeloupe was that the British sugar islands would not be able to supply the enlarged American market. Since the main motive for the war had been the conquest of Canada in order to remove the French menace, the matter was not one for serious argument at Whitehall or Westminster. But Grenville was among those who favoured acquiring Guadeloupe and not Canada, and Lord Bute seemingly proposed that idea to Pitt, only to be rebuffed. 'Fy, Fy, My Lord. No, No.' ${ }^{34}$

In 1763 Britain ended the war in possession of all North America east of the Mississippi River, buttressing the fifteen old colonies along the Atlantic seaboard from Newfoundland to Georgia. The problem of how to organise and control the new territory loomed large in the public mind, but a preliminary settlement was to be promptly enacted by a Royal Proclamation of 1763 . Three new colonies were created, one of Quebec from the old French colony and restricted to the St Lawrence valley, and two from territory ceded by Spain. These were East Florida, roughly equivalent to the modern state of Florida, and West Florida, a coastal strip along the Gulf of Mexico to the mouth of the Mississippi. Since nearly all the new European inhabitants were French or Spanish, no elected assemblies were permitted, such as existed in the older British colonies. The remainder of the new territory, north and south of the Great Lakes and in the Mississippi valley, was to be a vast Indian reservation, where trade was permitted but settlement forbidden, a veto avowedly temporary and designed to avert Indian troubles. The British army in North America, the financing of which was to cause so much trouble, was almost entirely stationed in the new colonies and the Indian reservation, as much to control the inhabitants there as to defend them.

The British government's attempt to raise money for army costs was the immediate occasion of the quarrel with the older colonies; but officials in both America and London had long been aware of the defiant attitude of the colonists. Demonstrated pragmatically by contravention of such trade laws as did not suit them, it had been shown more directly in the weakening of royal government, as the elected assemblies deployed the power of the purse and other weapons to encroach on the authority of governors and their subordinates. During little more than a decade from 1763 this negative and empirical defiance would become a positive denial of the right of the 
British Parliament to tax and legislate for colonies which had their own assemblies.

The other major new acquisition was in India, where Robert Clive's victory at Plassey in 1757 over the Nawab of Bengal transferred to the East India Company effective control of that province, albeit under the nominal rule of puppet Nawabs. But a trading company was unsuited to be a territorial ruler, and as early as 1759 Clive himself, Governor there from 1758 to 1760 , wrote to Pitt on that very point. 'So large a sovereignty may possibly be an object too extensive for a Mercantile Company, and it is to be feared they are not of themselves able, without the nation's assistance, to maintain so wide a dominion. ${ }^{35}$ For the democratic constitution of the Company offered ample scope to those who sought to exploit the prospects of great wealth, together with considerable patronage and political power. The final word lay with the 2,000 or more shareholders who possessed the voting qualification of $£ 500$ stock. Meeting as the General Court of Proprietors, they decided the biannual dividend, and every April chose by secret ballot the twenty-four Directors responsible for the management of the Company. The immediate result of the news of Plassey was a successful coup at the 1758 election of Directors. Laurence Sulivan, a former Company servant, became Chairman after winning a majority of fourteen to ten Directors. He was to hold power for six years, but among those offended by his reforming measures was Clive himself, who returned to Britain in 1760 with a fortune estimated at $£ 300,000$, and with a recent grant to him by the Nawab of Bengal of an annual jagir or land rent of $£ 27,000$, payable through the Company. Conflict between Clive and Sulivan was postponed because Sulivan was anxious to avoid a quarrel with the returning hero. Clive indeed had no desire to run the Company, but circumstances soon drew him into Company politics.

One way or another, India was destined to become a major political issue of the new reign. The problems of ruling a province of twenty million inhabitants could not be left to the East India Company. There was soon growing concern over both misgovernment in Bengal and the return to Britain of wealthy 'nabobs', company servants who were commonly believed to have made their money at the expense of both Company and India. That the Company seemed now to be a financial honey pot attracted the attention of government and speculators alike, and its management became part of the political scene. The General Court began to meet frequently, nearly once a fortnight by the early 1770s, with over a hundred MPs sitting as 
proprietors and dominating its debates. ${ }^{36}$ Chatham in 1769 referred to its meetings as 'little Parliaments'. ${ }^{37}$

If India was a new problem, Ireland was an old one: but in the mideighteenth century the challenge to British control came not from the downtrodden Catholics, but from the Protestant Ascendancy, even though this ruling Anglican minority numbered only one-tenth of the population. The somewhat larger minority of Presbyterians, mostly resident in Ulster, were still effectively excluded from power-sharing. As for the Catholic majority, about three-quarters of the Irish people, among the numerous restrictions imposed on them by the Penal Code of 1690 to 1730 was exclusion not only from Parliament, but also from the franchise and all offices, local and national. Legal sanctions were reinforced by military coercion: an Irish army of 12,000 men was mostly deployed in small, scattered units to act as a police force rather than for its ostensible purpose of national defence: the Whiteboy peasant riots of the 1760s were suppressed without difficulty. The Ascendancy was very much a Protestant garrison, and the Irish political system, very similar in structure to that of Britain, was an Anglican preserve.

Ireland was perceived in Britain as an imperial problem, but it was one complicated by many political and personal links that spanned the Irish Sea. Ireland was ruled by a Lord-Lieutenant, always a British peer, in the name of George III, who therefore took a personal interest in appointments. The Viceroy formed part of the ministry in London, and a change there almost always entailed a replacement in Dublin. The Lord-Lieutenant would take over with him a Chief Secretary of his own choice, a key figure with responsibility for management of the Irish House of Commons: the young Henry Grattan referred to the 1770 incumbent as 'the Macaroni Prime Minister', a snide reference to his manners and inferior status. ${ }^{38}$

The chief political task of the Lord-Lieutenant was management of the Irish Parliament, which met only in alternate years. It could not vote him out of office, but there was the need to obtain some finance, for the Irish Hereditary Revenue did not meet the full cost of government. The British government, moreover, always wanted to avoid the public embarrassments of hostile resolutions and awkward legislation. But, for a variety of reasons, the Irish Parliament was often more difficult to control than that at Westminster. As in Britain, the House of Lords, small in size, was easier to manage. Of 140 lay peers in 1775 , about a third were absentee, mostly British politicians given Irish titles. The four archbishops and eighteen bishops of the Anglican Church of Ireland were usually as amenable to government influence 
as their fellows at Westminster, and most peers also felt the pull of offices and honours. The hard core of opposition lords was usually under a dozen. ${ }^{39}$ But the Irish House of Commons was often troublesome to Dublin Castle.

The 300 Irish MPs were, as in Britain, mainly landowners who secured their own elections, for there were few patrons who controlled more than one constituency. They all sat for two-member constituencies, 32 counties and 118 boroughs, whose electoral franchises were similar to those in Britain. The forty-shilling freehold county qualification produced altogether 50,000 voters. Dublin headed the boroughs with 4,000 , but 75 boroughs had 13 voters or less, including nearly all the 55 corporation boroughs. The Irish Commons therefore comprised country gentlemen and relatives of peers, few of whom owed any thanks to government for their elections. ${ }^{40}$

It was a more difficult problem of management than British ministers faced at Westminster. There was little sense of loyalty to an absent sovereign. On the contrary, opponents of government could adopt a 'Patriot' stance by voicing Irish grievances, for Ireland had not obtained many of the British safeguards of liberty. There was no Habeas Corpus Act, and no security of tenure for judges. A Parliamentary general election need take place only on the death of a sovereign, since Ireland had no equivalent to a Septennial Act, and the election of 1728 had been the only one of George II's reign. By 1760 there was mounting Irish pressure to remedy these constitutional defects. But above all there was the grievance of the so-called Poynings Law of 1494, whereby all Irish legislation had to be approved by the British Privy Council, by now in effect the ministry, which had the right to accept, refuse or modify it. Other parts of Poynings Law had been modified in practice over the course of time. The Irish Parliament was now allowed to introduce legislation, 'by a liberal interpretation of the law', so Prime Minister Lord North told the British House of Commons on 3 May $1770 .{ }^{41}$ Whether initiation of financial business was still the preserve of the Irish Privy Council remained, however, a point of dispute. More recently a Declaratory Act of 1720 had asserted the right of the Westminster Parliament to legislate for Ireland 'in all cases whatsoever'. That power had seldom been exercised, apart from economic legislation concerned with the whole British Empire. Many of these Irish grievances existed more in theory than in practice, but they signified the inferior status of Ireland, and discussion of them became a regular feature of Irish Parliamentary debates after 1760 . 
The crux of the Irish problem facing Britain was not the potentially recalcitrant behaviour of the Dublin Parliament. It lay in the circumstance that British Lord-Lieutenants had in effect sold the pass, by conceding too much power to Irish politicians. Since the Irish Parliament met only every other year, it had become the practice for the Viceroy to reside in Ireland for little more than the Parliamentary sessions, on average some eight months every two years. Otherwise Ireland was ruled by Irish magnates appointed Lords Justices. This habit of merely intermittent direct British control inevitably resulted in power being transferred to the Irish aristocracy. Opposition peer Lord Charlemont penned this sardonic account of the state of affairs in the early 1760s. 'A certain set of men, whose only principle was the lust of power and emolument, and whose only ability was the art of party management, had then such influence in Parliament, an influence as ill-directed as it was undue, that the Lord Lieutenant was wholly in their power and could confer no favour but at their recommendation. They were styled "undertakers", ${ }_{42}$

Their final takeover of power came when the Duke of Bedford was Lord-Lieutenant from 1757 to 1761 . He began, indeed, by trying to govern without the aid of the faction leaders who had dominated the Irish political scene for decades, albeit often as rivals: Lord Shannon, who as Henry Boyle had been Irish Speaker from 1733 to 1756, and possessed an electoral power base in the Cork region; George Stone, who was Primate of Ireland as Archbishop of Armagh, and wellconnected in British politics; and John Ponsonby, whose family was intermarried with the Cavendishs, had been Speaker since 1756, and was First Commissioner of the Revenue Board, a post that gave him more patronage than the Viceroy. Abandoning confrontation, Bedford appointed them Lords Justices during his absence of 1758-59. Self-interest led the three men to form an alliance that dominated Irish politics for the next six years. Bedford, under pressure from a ministry that did not want a wartime Irish crisis, had sold out to the Undertakers, and his 1761 resignation was born of frustration, a compound of anger and despair. ${ }^{43}$ "That country was come to such a pass that no man that was at ease or had another character to lose would care to go among them.' So did the Duke of Devonshire, himself a former viceroy, explain to Lord Bute the Duke of Bedford's refusal 'to go any more' to Ireland as Lord-Lieutenant. ${ }^{44}$ His legacy was an Irish problem to be added to others that arose more directly out of the Seven Years War. The high moral tone adopted by George III ensured that the Irish Undertakers would be included among the bad men whose day of reckoning had come. 


\section{Notes}

1 Malmesbury Letters, I, 202.

2 BL Add. MSS. 35410, fo. 140.

3 The political crisis of $1754-57$ is discussed in detail in Clark, Dynamics of Change.

4 Grenville Papers, I, 405.

5 BL Add. MSS. 32945, fos 1-2.

6 BL Add. MSS. 32905, fo. 14.

7 Namier, Age, pp. 419-21.

8 BL Add. MSS. 32974, fo. 170.

9 Christie, PH, 6 (1987), 47-68.

10 BL Add. MSS. 33001, fos 357-63.

11 Malmesbury MSS. Photocopies A883.

12 BL Add. MSS. 38206, fo. 20.

13 BL Add. MSS. 32898, fos 223-4. For the modern reappraisal of Pitt as a war minister see Middleton, Bells of Victory, passim.

14 Middleton, Bells of Victory, pp. 150-69.

15 On this see McKelvey, George III and Lord Bute: The Leicester House Years.

16 Bute Letters, pp. 18, 45.

17 BL Add. MSS. 32972, fos 193-4; 32973, fo. 84.

18 BL Add. MSS. 32945, fos 1-2.

19 Grenville Letter-Books, II. G. Grenville to T. Pitt, 22 Oct. 1768.

20 Malmesbury MSS. Photocopies B925.

21 BL Add. MSS. 32990, fos 61-2.

22 Malmesbury MSS. Photocopies B902. Camden had just broken with Chatham to stay on in office.

23 BL Add. MSS. 51379, fos 175-6.

24 Grenville Papers, IV, 407.

25 Chatham Anecdotes, I, $418 \mathrm{n}$.

26 Chatham Anecdotes, II, 213-17. For opposition belief in 'secret influence' at this time see Hamer, Thesis, pp. 244-65.

27 Reitan, BIHR, 47 (1974), 186-201. For the complete Civil List expenditure between 1752 and 1769 see Commons Journals, XXXII, 466-603, 626-7, 729-30.

28 Bute Letters, p. 28.

29 Brooke, King George III, pp. 88, 390-1.

30 Corr. of George III, II, 204.

31 Scott, British Foreign Policy, p. 89 n.

32 Grafton Autobiography, p. 168. 
33 Tracy, Navies, pp. 8-31.

34 Malmesbury MSS. Photocopies B885. For accounts of this controversy see Grant, AHR, 17 (1911-12), 735-43, and Namier, Age, pp. 273-82.

35 Chatham Papers, I, 389-90.

36 Bowen, HJ, 34 (1991), 857-72.

37 Grafton Autobiography, p. 237. For the East India Company see Sutherland, East India Company, esp. pp. 49-269, and Bowen, Revenue and Reform.

38 Macartney Papers, p. xxxii, n. 82.

39 Johnston, Great Britain and Ireland, pp. 256-69.

40 Johnston, Great Britain and Ireland, pp. 120-78, 321-30.

41 BL Egerton MSS, 222, fo. 70.

42 HMC Charlemont, I, 144-5.

43 For the Bedford Viceroyalty see Powell, Thesis, pp. 57-82.

44 Devonshire Diary, p. 78. 